\title{
Behaviour of house mice in semi-confined conditions: influence of spatial separation and population size
}

\author{
Wiera WALKOWA, Elena KOTENKOVA, \\ Krystyna ADAMCZYK and Miłosława BARKOWSKA
}

\begin{abstract}
Walkowa W., Kotenkova E., Adamczyk K. and Barkowska M. 1998. Behaviour of house mice in semi-confined conditions: influence of spatial separation and population size. Acta Theriologica 43: 241-254.

Quantitative scores for 4 behavioural patterns, especially those of an antagonistic nature, were recorded from wild individual of Mus musculus musculus Linnaeus, 1758 living in semi-confinement in an outdoor enclosure divided into four pens. The enclosure was "permeable", in that mice were able to move between pens and between the enclosure and the outside. The population was monitored by the capture-mark-recapture method. In the spring of 1988 and 1989 the behaviour of mice trapped in the enclosure was studied in unisexual encounters in a neutral arena. There were no significant differences in scores for behaviour in relation to the degree of spatial separation of the places of capture of individuals paired together (except in the number of attempts to escape noted for females in 1989 and the total activity noted for males in 1988). Males and females did not differ significantly in scores for aggressive behaviour, but mice were more aggressive and more active in 1989 when the population in the enclosure was smaller, than in 1988, when it was larger.

Key words: Mus musculus, aggressive behaviour, enclosure population, population size

Department of Vertebrate Ecology, Institute of Ecology PAS, Dziekanów Leśny, 05-092 Łomianki, Poland (WW, KA, MB); Severtzov Institute of Ecology and Evolution RAN, Leninskyi prospect, 33, 117071 Moscow, Russia (EK)
\end{abstract}

\section{Introduction}

According to the classic studies by Crowcroft $(1954,1955)$, and Crowcroft and Rowe (1963), social structure in groups of house mice (Mus musculus musculus Linnaeus, 1758) is formed and maintained by antagonistic interactions between males, while the aggression of females is usually low. Two types of social structure have been described in small and in large enclosures: a hierarchical system and individual territoriality. In both cases, as mentioned, social relations are maintained by aggressive interactions between males (Guralnik et al. 1972, Mackintosh 1973, Lloyd 1975, Lidicker 1976, Singleton and Hay 1983, Sokolov et al. 1988, 1990). Mice are very aggressive towards intruders (Andrzejewski et al. 1963, Crowcroft and Rowe 1963, Rowe and Redfern 1969, Guralnik et al. 1972, Zegeren 1980), with aggressive behaviour in males being particularly obvious in the context of the 
establishment and defence of territory. In females, such behaviour appears especially in defence of the litter. The self-regulation hypothesis postulates that aggression is an important factor in the regulation of rodent populations (Christian 1950, Chitty 1960), and it has been found to affect mortality, reproductive success and emigration in house mice (review Archer 1970, Zegeren 1980). However, most of this information was obtained in studies of caged or enclosed populations (Crowcroft 1955, Kamenov 1973, Lloyd 1975, Lidicker 1976), with very few studies having involved natural habitats (Hurst and Berreen 1985).

With this in mind, we have been monitoring a population of house mice inhabiting a semi-confined outdoor enclosure since 1986. This led us to suggest that emigration occurred as a result of social pressure imposed by nearest neighbours (Walkowa et al. 1989). The aim of the present study was to follow this by examining the behaviour (especially the aggression) of adult males and females in relation to spatial separation and population numbers. We predicted that a greater incidence of aggressive behaviour would be associated with: (1) greater population size, and (2) greater spatial separation of individuals.

\section{Material and methods}

Work was done in a $600 \mathrm{~m}^{2}$ outdoor enclosure that was "permeable", ie not "mouseproof", and thus colonized spontaneously by house mice from the surroundings. The enclosure was divided into 4 equally-sized pens (Fig. 1) by way of brick walls extending $80 \mathrm{~cm}$ above, and $60 \mathrm{~cm}$ below, ground level. Upper parts of the walls were constructed of wire mesh, as was the top of the enclosure. In spite of the partitioning, mice could move between pens, and between the enclosure and the surrounding habitats (Walkowa et al. 1989). Direct behavioural observations were made impossible by grass in the enclosure and by the fact that the mice had burrows. In consequence, the capture-mark-recapture method was employed - twice a month from the inception in April 1986 to June 1988, monthly after that to April 1993, and next once every 2 months. Each pen had twelve evenly-distributed sites with four live traps provisioned with oats. The quantity of oats was constant $(8 \mathrm{~kg}$ per week in the enclosure). Population size were estimated by the "calendar of catches" method (Petrusewicz and

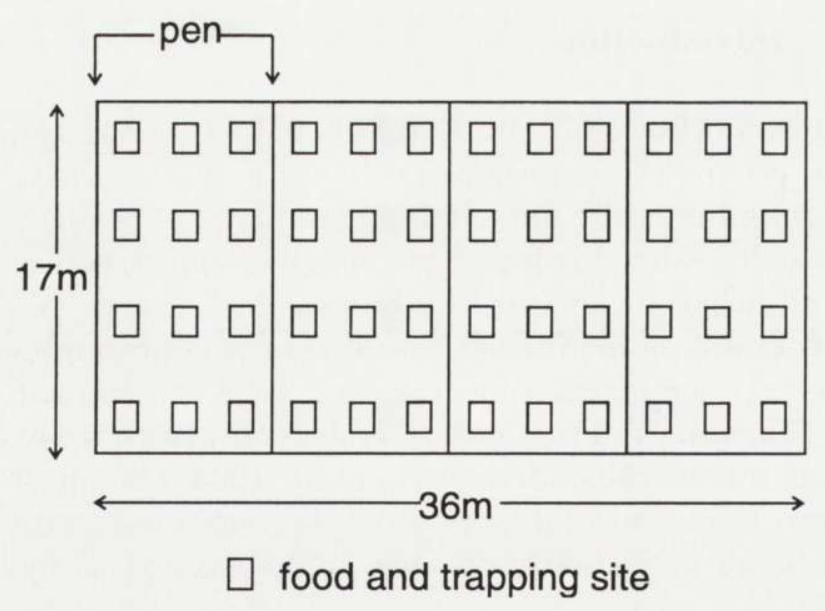

Fig. 1. Scheme of the enclosure. 
Andrzejewski 1962), as the minimum numbers known to be alive. To illustrate long-term changes in abundance, Fig. 2 treats the data as if monitoring had been carried out once a month.

Behavioural trials were performed in the period May 16-24 1988, using 30 adult males and 55 adult females trapped in the enclosure, and between May 29 and June 21989 , using 9 trapped adult males and 21 trapped adult females. Use was also made of 7 adult males and 1 adult female trapped outside the enclosure (in fields and in houses) during May 1989. All the mice were reproductively active (females - open vagina, males - testes in scrotum). Females with visually-apparent pregnancy or lactation were excluded. Body weights were in the range $13-22 \mathrm{~g}$.

Social interactions and levels of aggression of mice from the enclosure were studied in a standard unisexual pair encounter test carried out within 30-60 minutes of trapping, under normal day light conditions. Mice of similar body weight were paired in a neutral arena (a glass chamber measuring $60 \times 30 \times 35 \mathrm{~cm}$ ), with the 2 individuals being introduced to the chamber simultaneously, in the live-traps in which they had been caught. The chamber was divided by a partition, with each half receiving a trap that was removed as soon as it was vacated. Mice were allowed to explore their own part of the chamber for 5 minutes before the partition was removed.

In the next ten minutes the investigator, always the same person, observed behaviour and recorded the number of events under the 4 following categories of behavioural patterns: (1) aggressive interaction - chases, fights, boxing, threats, side uprights involving pushing movements of forepaws, tail rattles, circling around an opponent; (2) identificative interaction - naso-nasal, naso-anal and investigations of different parts of body; (3) amicable interaction - crowding (sitting together) and grooming (only allo-grooming, as the excessive grooming usually considered aggressive was observed in only a few trials and excluded from analysis); (4) attempts to escape - jumping up the walls, climbing. The total number of events in these 4 categories of behaviour was considered characteristic of locomotory or general activity.

On the basis of qualitative and quantitative scores for aggressive behaviour each tested pair encounter was classified as showing: (1) a high level of aggression - with mice fighting each other, chasing and boxing. Aggressive interactions were mostly observed during the first $2-3$ minutes of the

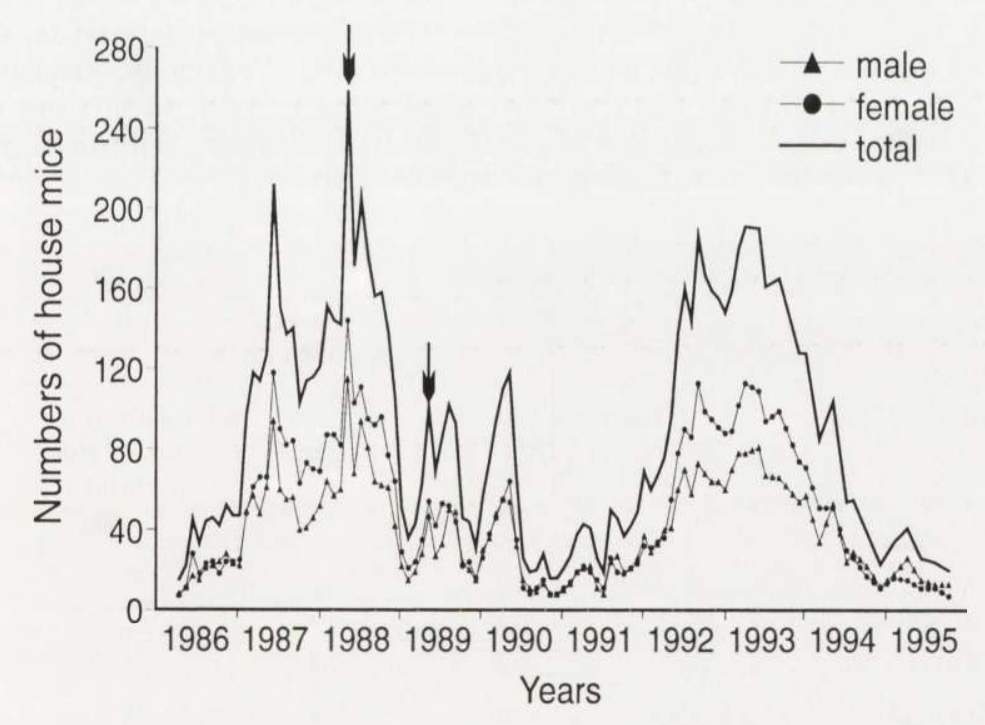

Fig. 2. Changes in numbers of house mice in the enclosure (diagram includes data from monitoring once a month). Arrows indicate the times of experiments. 
trial, although they did in some cases continue to the end; (2) a low level of aggression - with some other elements of aggressive behaviour like side uprights, threats and pushing observed. Low-level aggressive interactions were observed within 1-2 minutes of the start of the trial; (3) non-aggressive interaction - with aggressive behaviour not observed at all. Individuals sniffed one another, sat together for 3-5 minutes, or sometimes mostly exhibited the escape actions, jumping and climbing.

The proportion of pairs belonging to each of the above three groups was calculated and used as a measure of the level of aggression in the population.

As the main response of mice to an intruder is an increase in aggression (Andrzejewski et al. 1963, Rowe and Redfern 1969, Zolotarev 1980, Sokolov et al. 1988), it may be assumed that behavioural patterns relate to whether mice belong to the same social group or to different, spatially-separated ones. In the case of this study, mice caught at the same trapping site were assumed to belong to the same family/social group, while those caught at different sites, especially in different pens, were considered members of different family/social groups. On this basis, 4 degrees of spatial separation were acknowledged in the selection of individuals for pair encouters. The 1st degree of separation involved mice from the same trapping site (in 1988 only); the 2nd mice from the same pen, but different trapping sites; the 3 rd mice from different pens and the 4 th mice from within and beyond the enclosure (in 1989 only).

A total of 125 pair encounters were observed (Table 1), with ANOVA (one factor analysis of variance) used to account for the effects of: (a) spatial separation, (b) the year of experimentation and (c) sex, on the quantitative scores in each behavioural pattern.

Some mice were used more than once in trials, and this raised doubts as to whether the result of a first encounter (a "win" in a fight or a "defeat") might affect those of subsequent encounters. However, the length of time mice remained captive was short, with re-release at the place of capture immediately following the arena tests. Since a given mouse thus spent more time with the population than away, the maintenance of established social relations in the population should have been favoured and thus no effects on individual behaviour noted during consecutive pair encounters in the neutral arena. To verify this assumption, we also analysed the quantitative scores for behaviour obtained from 10 individuals used in as many as 5 consecutive pair encounters. No significant effects of the number of pair encounters an individual had been involved in, on the mouse behaviour were found (ANOVA, one factor analysis of variance, $F=0.97$ for aggressive interaction; $F=0.58$ for identificative interaction; $F=0.69$ for amicable interaction; and $F=0.56$ for attempts to escape). These results suggest that in our case "previous experience effect" did not influence behavioural patterns and dominant or subordinate position in consecutive encounters. Consequently the results for all behavioural observations were treated as independent data.

Table 1. The number of pair encounters of house mice

\begin{tabular}{|c|c|c|c|c|c|c|}
\hline \multirow{3}{*}{ Year } & \multirow{3}{*}{ Sex } & \multicolumn{5}{|c|}{ Sites of capture } \\
\hline & & \multicolumn{2}{|c|}{ In the same pen } & \multirow{2}{*}{$\begin{array}{l}\text { In different } \\
\text { pens }\end{array}$} & \multirow{2}{*}{$\begin{array}{l}\text { Inside and } \\
\text { outside the } \\
\text { enclosure }\end{array}$} & \multirow[t]{2}{*}{ Total } \\
\hline & & $\begin{array}{c}\text { In the same } \\
\text { site }\end{array}$ & $\begin{array}{c}\text { In different } \\
\text { sites }\end{array}$ & & & \\
\hline \multirow[t]{3}{*}{1988} & Males & 4 & 17 & 16 & - & 37 \\
\hline & Females & 18 & 22 & 18 & - & 58 \\
\hline & Total & 22 & 39 & 34 & - & 95 \\
\hline \multirow[t]{3}{*}{1989} & Males & - & 3 & 3 & 7 & 13 \\
\hline & Females & - & 6 & 10 & 1 & 17 \\
\hline & Total & - & 9 & 13 & 8 & 30 \\
\hline
\end{tabular}


In 1988 no mice were trapped outside the enclosure during the experiment while in 1989 none were caught at the same trapping site simultaneously (in the same census). This left comparison of data for 1988 and 1989 possible for trials involving the 2nd and 3rd degrees of separation. For the same reason, analysis of the effects of spatial separation on quantitative scores for behaviour patterns could use data for the 1st, 2nd and 3rd degrees of separation in 1988 and the 2nd, 3rd and 4th degrees in 1989.

The dependence of scores on one of the three factors mentioned above (for example, degree of separation) was analysed with account taken of the two other factors (in our case - sex and years). If the effect of a factor on behavioural events (scores) was not significant, those of the two others were tested independently of it (in our example independently of the degree of separation).

The effects of spatial separation, the year of experimentation and sex on the proportion of aggressive pair encounters was analysed by $\chi^{2}$-test, applying a probability level of at least 0.05 for significant differences.

\section{Results}

The dynamics of the mouse population in the semi-confined conditions of the enclosure were studied for ten years (Fig. 2). Phases of increase, peaking, decline and low abundance followed one another. The population was low in 1986, but began to increase quickly from the beginning of 1987 . Two periods of high numbers lasting 1.5 years were observed during the study (in 1987-1988 and 1992-1993). Phases of high abundance were separated by ones of decline and low numbers lasting 3.5 years. Seasonal changes in numbers were observed in some years. Spring (April-June) peaks were observed in 1987, 1988, 1989, 1990 and 1993. These lasted 1-2 months in 1987, 1988 and 1990, but 3-4 months in 1989 and 1993. In 1992, a peak was observed in autumn, and there were no clear seasonal changes in 1986 and 1991. As phases in population dynamics can last for a few months, they are unrelated to season. It is clear from the above that population sizes were very different in the two periods of observation of behaviour, for example in spring 1988, numbers were more than double those of 1989 (Table 2).

The level of aggression was generally low for both sexes. Only $6 \%$ of male pairings and $12 \%$ of female pairings were characterized by high levels of aggression, and about half ( $62 \%$ of male pairings and $53 \%$ of female pairings)

Table 2. The number of individuals in the enclosure at the time of experiments.

\begin{tabular}{|c|c|c|c|c|c|}
\hline \multirow{2}{*}{ Date } & \multirow{2}{*}{ Sex } & \multirow{2}{*}{ Adults } & \multirow{2}{*}{$\begin{array}{c}\text { Subadults } \\
\text { and juveniles }\end{array}$} & \multicolumn{2}{|c|}{ Total } \\
\hline & & & & Numbers & Density (ind.$/ \mathrm{m}^{2}$ ) \\
\hline \multirow[t]{3}{*}{ 16-24 May 1988} & Males & 34 & 75 & 109 & 0.18 \\
\hline & Females & 62 & 74 & 136 & 0.23 \\
\hline & Total & 96 & 149 & 245 & 0.41 \\
\hline \multirow[t]{3}{*}{29 May - 2 June 1989} & Males & 13 & 34 & 47 & 0.08 \\
\hline & Females & 24 & 29 & 53 & 0.09 \\
\hline & Total & 37 & 63 & 100 & 0.17 \\
\hline
\end{tabular}


witnessed no aggressive behaviour at all. Only in two trials was it possible to distinguish dominant individuals. These were males exhibiting a high level of aggression and winning in pair encounters.

In females, the level of aggression (the proportion of aggressive pairs) was only related to the degree of spatial separation in 1988 (Fig. 3). In this case, the proportion of female pairings with aggressive behaviour was larger with a greater degree of separation $\left(\chi^{2}=9.66, \mathrm{df}=4, p=0.05\right)$, though this in fact reflected an increase in the proportion of pairs exhibiting low-level, rather than high-level, aggression. The level of aggression did not depend on the degree of spatial separation of females in $1989\left(\chi^{2}=0.65, \mathrm{df}=2, \mathrm{~ns}\right)$, or of males in either year (1988: $\chi^{2}=0.96, \mathrm{df}=2$, ns; 1989: $\chi^{2}=1.93, \mathrm{df}=3, \mathrm{~ns}$ ).

The effect of the year of experimentation on the proportion of aggressive pairs was only significant for males $\left(\chi^{2}=10.34, \mathrm{df}=2, p<0.001\right)$, with relatively more male pairings involving aggressive behaviour in 1989. Some pairings tested in this year were characterized by high levels of aggression (Fig. 4). There were no significant differences between the years for females $\left(\chi^{2}=2.63, \mathrm{df}=2, \mathrm{~ns}\right)$. Finally, males and females were not found to differ in the proportion of aggressive pairs (in 1988: $\chi^{2}=4.95, \mathrm{df}=2, \mathrm{~ns}$; in 1989: $\chi^{2}=0.68, \mathrm{df}=2, \mathrm{~ns}$ ).

The relationship between the degree of spatial separation and the quantitative scores for each category of behaviour pattern (aggressive, identificative, amicable and attempts to escape) was then analysed.

In females, a significant effect of the degree of spatial separation was found for scores concerning attempts to escape, identificative interaction and total activity, though only in 1989 (Table 3). Furthermore, spatial separation only really affected attempts to escape, because no effect on the other two variables remained

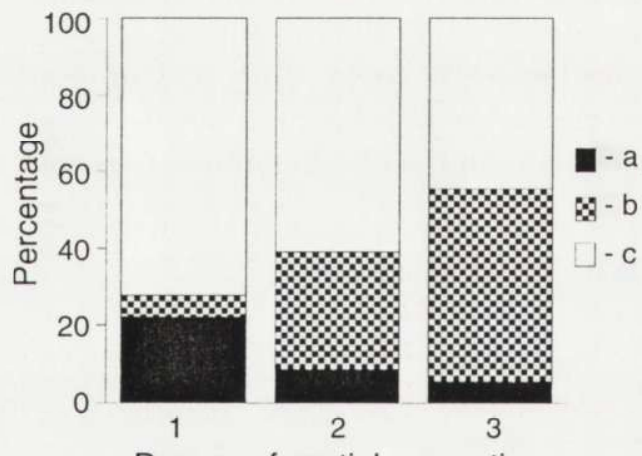

Degree of spatial separation

Fig. 3. Proportion of female pairs exhibiting different levels of aggression in 1988, in relation to degree of separation. $\chi^{2}=9.66, \mathrm{df}=4, p=0.05$. $\mathrm{a}-$ high aggressive, $\mathrm{b}$ - slight aggressive, c non aggressive.

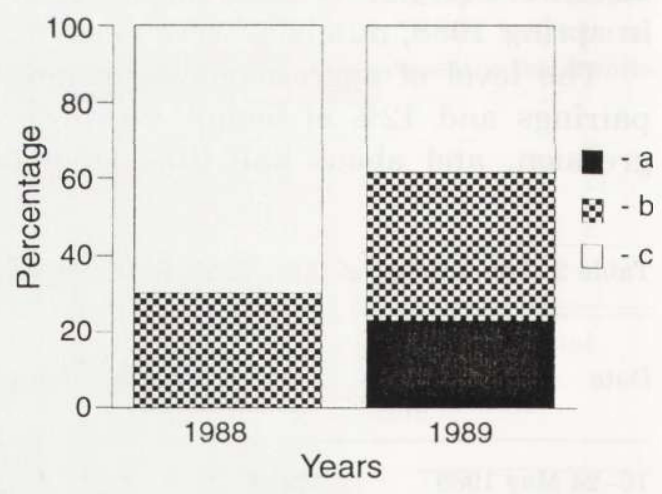

Fig. 4. Proportion of male pairs exhibiting different levels of aggression in 1988 and 1989. $\chi^{2}$ $=10.34, \mathrm{df}=2, p<0.001$. a - high aggressive, $\mathrm{b}$ - slight aggressive, $\mathrm{c}$ - non aggressive. 


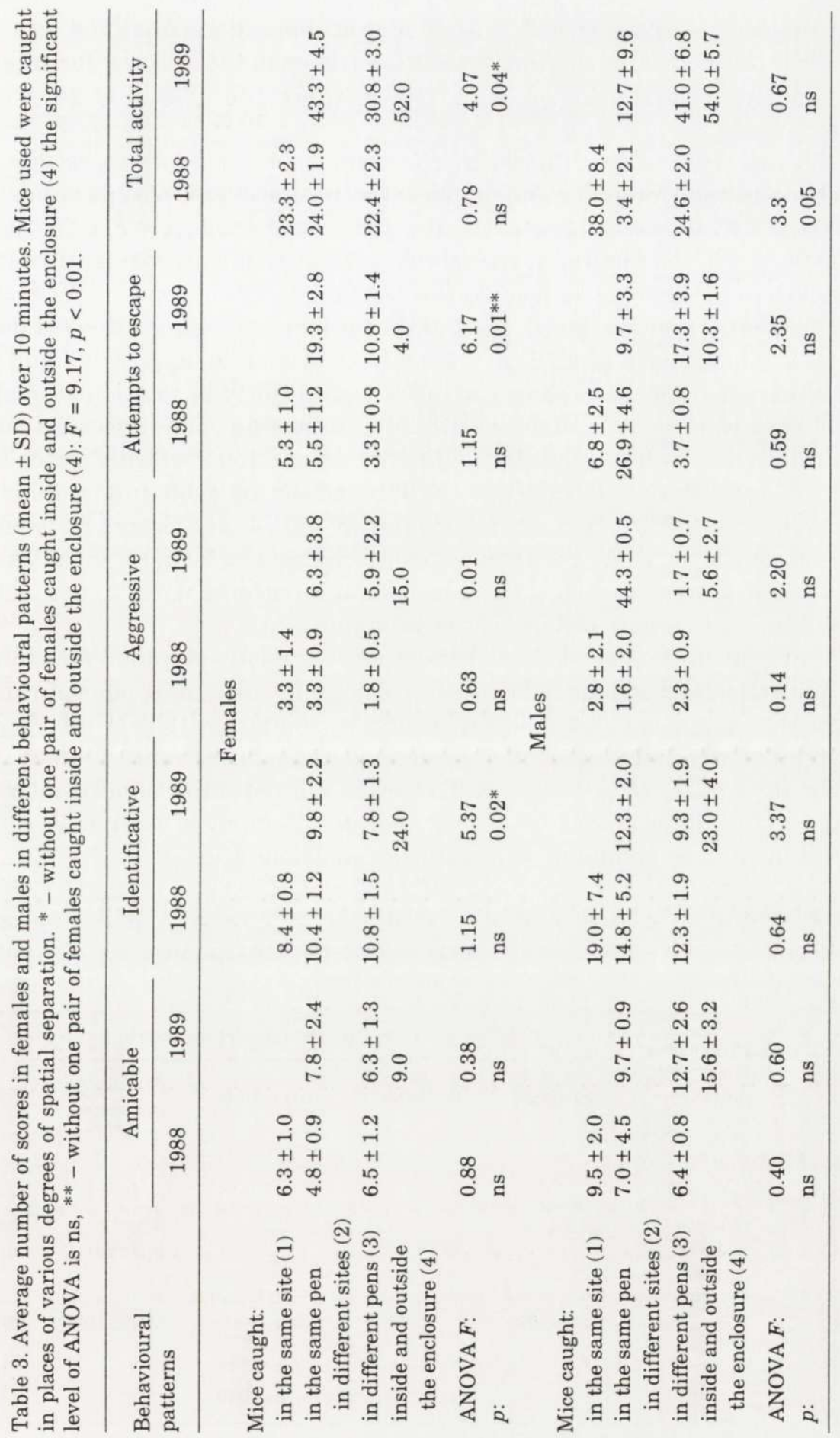


when the one pairing with a degree of spatial separation equal to 4 was excluded. In males, the degree of spatial separation affected 1988 scores for total activity significantly, with the latter being lower where the degree of separation was greater (Table 3).

1988 and 1989 data differed in the number of attempts to escape from the chamber observed for males and females (for the 2nd degree of separation: $F=8.86$, $p=0.04 ; F=27.07, p<0.01$ respectively, and for the 3rd degree $F=25.49, p<0.01$; $F=30.98, p<0.01$ ). Similarly, the scores for total activity were significantly higher in 1989 than in 1988 for both sexes (for the 2nd degree of separation: $F=8.10, p<$ 0.001 for males and $F=20.50, p<0.0001$ for females, and for the 3rd degree: $F=$ $9.67, p<0.006$ and $F=4.69, p<0.004$ ). As scores for aggressive and amicable interactions had not been shown to differ significantly in relation to spatial separation, they were tested independently of it, to test for differences between years. Such differences were found: for aggressive interactions in both males $(F=8.93$, $p<0.01)$ and females $(F=4.81, p<0.04)$; and for amicable interactions in males $(F=17.12, p<0.0001)$, but not in females $(F=0.74, \mathrm{~ns})$. Scores for identificative interactions did not differ between years in females: $F=0.84$, ns; in males: $F=1.21$, ns). Average scores for each of the 4 behavioural patterns were higher in 1989 than in 1988 (in cases where differences were significant).

Significant differences between the sexes were only obtained for identificative and amicable interactions. Males showed significantly more identificative interactions than females in both $1988(F=8.68, p<0.01)$ and $1989(F=9.73, p<0.01)$, and significantly more amicable interactions in the latter year $(F=8.28, p<0.01)$, but not the former $(F=1.98, \mathrm{~ns})$. The sexes did not differ significantly in scores for aggressive interactions $(F=0.69, \mathrm{~ns})$ or attempts to escape $(F=1.05, \mathrm{~ns})$. Results have been compiled schematically in Table 4.

Table 4. Dependence of behavioural patterns on degree of spatial separation, sex, and study years. “+” - significant dependence $(p<0.05)$, “-” - no significance.

\begin{tabular}{|c|c|c|c|c|c|c|}
\hline \multirow{2}{*}{ Factor } & \multirow{2}{*}{$\begin{array}{l}\text { Proportion } \\
\text { of aggressive } \\
\text { pairs }\end{array}$} & \multicolumn{5}{|c|}{ Average number of interactions } \\
\hline & & Aggressive & Identificative & Amicable & $\begin{array}{l}\text { Attempts } \\
\text { to escape }\end{array}$ & Total activity \\
\hline $\begin{array}{l}\text { Degree of } \\
\text { spatial } \\
\text { separation }\end{array}$ & $\begin{array}{l}- \\
\text { (+ only in } \\
\text { females } \\
\text { in 1988) }\end{array}$ & - & - & - & $\begin{array}{l}- \\
\text { (+ only in } \\
\text { females } \\
\text { in 1989) }\end{array}$ & $\begin{array}{l}- \\
\text { (+ only in } \\
\text { males } \\
\text { in } 1988)\end{array}$ \\
\hline Years & $\begin{array}{l}\text { - in females } \\
+ \text { in males }\end{array}$ & $\begin{array}{l}+ \\
1989>1988\end{array}$ & - & $\begin{array}{l}\text { - in females } \\
+ \text { in males }\end{array}$ & $\begin{array}{l}+ \\
1989>1988\end{array}$ & $\begin{array}{l}+ \\
1989>1988\end{array}$ \\
\hline Sex & - & - & $\begin{array}{l}+ \\
\text { males }>\text { females }\end{array}$ & $\begin{array}{l}\text { - in } 1988 \\
+ \text { in } 1989\end{array}$ & - & $\begin{array}{l}\text { - in } 1988 \\
+ \text { in } 1989\end{array}$ \\
\hline
\end{tabular}




\section{Discussion}

It is usually difficult to observe the behaviour of small rodents in nature directly, so the technique of pair encounters in a neutral arena has been used widely to assess the effect of various factors on social behaviour, including the level intraand interspecific aggression (Krebs 1970, Murie 1971, Turner and Iverson 1973, Mihok 1976, Ambrose and Meehan 1977, McElman and Morris 1977, Llewellyn 1980, Zolotarev 1980). In general, authors have not analysed how that technique reflects the true relationships in nature between the animals studied. However, some results obtained using the technique have been confirmed by data obtained with other methods. For instance, in males of Microtus pennsylvanicus, aggression observed in a neutral arena increased as males in the population became reproductively active, and then decreased towards the end of the breeding season. Also, tail wounds in a field population were found to be more common during the breeding season (Turner and Iverson 1973). Kotenkova et al. (1989) and Sokolov et al. (1990) found no aggressive interaction between specimens of Mus spicilegus originating in the same mound (ie familiar individuals). In contrast, mice trapped in different mounds showed aggression in pair encounters in a neutral arena. The last example corresponds with data from direct observation showing increased aggression in cage populations when intruders appear (Andrzejewski et al. 1963, Crowcroft and Rowe 1963, Rowe and Redfern 1969). We used the method of pair encounters in a neutral arena for our semi-confined enclosure population, in order to test the behaviour of mice by analysing the quantitative scores for 4 behaviour patterns. The percentage of pairs exhibiting aggression was not large, so the level of aggression in the population was considered low. Support for this comes from the fact that no scars were found on the bodies of mice from the enclosure (either during the experiments, or through the 10 years of monitoring). Scars observed elsewhere in rodent populations (Southwick 1958, Crowcroft and Rowe 1963, Lidicker 1976) have been assumed to result from aggressive behaviour. We found only 2 dominant males in the enclosure population exhibiting a high level of aggression and being winners in aggressive interactions during pair encounters.

Many papers on various rodent species have shown that residents are usually aggressive towards strangers. This was true for enclosed populations (Andrzejewski et al. 1963, Crowcroft and Rowe 1963, Barnett and Evans 1965, Rowe and Redfern 1969) and for natural ones (McShea 1990). This is the basis for a frequent assumption that residents defend their individual or group home ranges against intruders.

In our case, there was reason to believe that the population might be composed of several social groups/families with their own ranges. Particular mice were strongly tied to particular trapping sites. Although there were 12 such sites in each pen, individuals were only usually caught in 5-7 during their lifetime (W. Walkowa, in prep.). The part of a home range individuals visited more frequently than by chance was even smaller and covered only 1-2 trapping sites. 
If several spatially-separated groups existed in each pen, the chance of capturing mice from different groups at the same trapping site was lower than the chance of capturing these mice at different trapping sites. Thus mice trapped at the same site should belong to the same social group (show the 1st degree of spatial separation), while those trapped at different sites should belong to different groups (ie show the 2nd degree of separation). Doubt may be expressed about the separation of social/family groups within a pen (ie if the 1st and 2nd degrees of separation differed), but there is no question that the population was divided into at least 4 spatially-separated groups due to the division of the enclosure into 4 pens. Although mice could move freely between pens, only $4 \%$ actually left a native pen to choose a new one as a place of residence (Walkowa et al. 1989). The majority of adults were trapped in their native pen only, until the end of their lives or their emigration from the enclosure. Taking into account this high degree of spatial separation, we assumed that individuals from these different groups were unfamiliar. As aggression in a population increases when intruders appear (Christian 1950, Andrzejewski et al. 1963, Barnett and Evans 1965), we expected our experiments to show that relations between mice from the same pen and different pens (and most especially between mice trapped in the enclosure and beyond it) should differ. However, the expected differences were either not found, or hard to explain when they were (eg the relation between the proportion of low-aggression females and the degree of separation in 1988 or the separation-related increase in the number of attempts to escape by females in 1989). The lack of separation-related differences in the majority of scores for the 4 behavioural patterns (especially aggressive interaction) might result from the development of some kind of familiarity between individuals from different pens in spite of spatial separation. Each mouse might be familiar with most inhabitants of the enclosure through olfactory communication or undetected exploration of the entire enclosure and surroundings. Yet explorers are most likely to be trapped in their own home ranges, where they may be socially-dominant or at least less subordinate.

No mice were trapped outside the enclosure in 1988, and only a few in 1989. But it was surprising to find that these individuals did not elicit increased aggression from enclosure residents. However, as the number of mice (especially males) in the enclosure was low and the number caught outside likewise (only 1 female and 7 males ), it is possible that there were too few data to test the effects of this degree of separation properly (Table 1).

The data on behavioural differences between the sexes in house mice are contradictory. Mackintosh (1981) found that, although all the described elements of behaviour could occur in both, there were differences in the frequency of the individual elements between males and females of the BALB/c strain. Males are more aggressive than females. According to some studies, females also defend territories (Reimer and Petras 1967, Ebert 1976), with pregnant and lactating individuals being the most aggressive (Lidicker 1976, Singleton and Hay 1983, Sokolov et al. 1990). In our experiments, significant differences beween the sexes 
were only obtained for identificative and amicable interactions. None of the other suspected differences (especially in relation to aggression) were found.

The dynamics of the population in the semi-confined enclosure were more or less periodical. Phases of the cycle were not connected with the seasons and could last for a few months. A stable food supply could have limited population size, but could not have regulated it, and since the enclosure was covered with wire mesh, predators could not have affected numbers. In consequence, we suppose that it was mainly intrinsic mechanisms of regulation that were operating in the population.

According to the hypothesis of population self-regulation (Christian 1950, Chitty 1960), changes in aggressive behaviour play an important role in regulating numbers. Many studies confirm that as populations increase, aggression increases too, with a high level of aggression inducing emigration. In confined populations with restricted emigration, aggression can induce an increase in mortality (especially nestling mortality) and a decrease in reproduction (review Archer 1970, Zegeren 1980). Our studies did reveal differences in quantitative scores for behaviour patterns between years with different population sizes. In both years experiments were conducted during the spring peaks following a short and sharp increase in population, when numbers in the enclosure were at their highest annual levels (Fig. 2). Work in 1988 coincided with the overall peak in population, while in 1989, within an overall downward trend, the population was less than half that in 1988. Although the level of aggression observed was not high in either year, it was higher in 1989 (for both males and females), while mice were also more active then than in 1988. Such changes in aggressive behaviour cannot be explained on the basis of the hypotheses of self-regulation from Christian or Chitty. However, other published data have shown that an increased level of aggression does not always occur when numbers are high. For example, Hall (1927) and Young et al. (1950) observed high-density cage populations in which such aggressive behaviour was lacking. Christian (1956) and Lloyd and Christian (1967) reported aggregates of inactive mice when densities were high. There were no aggressive interactions in some of the caged groups of laboratory and feral house mice studied by Kamenov (1973). According to his data, males in groups consisting of individuals with a "weak" type of nervous system did not exhibit aggression. Such males cannot form hierarchical social systems. Krasnov and Khokhlova $(1989,1994)$ also found that males in free-living house mouse populations trapped in the north-western Precaspian region on the shores of lakes and by irrigation canals were not always aggressive in pair encounters. In addition, the authors found that house mice in the far north did not form group hierarchical structures. Groups of caged males trapped on the Chucotka peninsula did not show aggression, even if these groups existed for a long time (Krasnov 1988, Krasnov and Khokhlova 1994). Mice have only appeared in this region recently and males in pair encounters exhibited no aggression and limited interaction of any kind.

Thus there are cases in which models of population self-regulation cannot explain observed results. For house mice plagues in the grain-growing areas of 
eastern Australia, Krebs et al. (1995) put forward a model based on the assumption that the trigger flipping a population from the low phase into the increase phase is increased aggression in the former (but not in the latter or in the peak phase). The increase in aggression results from a switch from nomadic behaviour to territorial behaviour. The peak is characterised by a decrease in aggression in comparison with the increase phase. Viitala (1981) also considered that abrupt decreases in natural populations of small rodents could not arise from aggression, if aggression ever regulated the number of adult males.

In high-density populations, reproduction can be reduced by olfactory cues suppressing oestrus blocking pregnancy, and delaying the sexual maturation of young (Bronson 1979, Drickamer 1986).

One possible explanation of our results may be that aggressive interactions are not a universal characteristic of populations of house mice, and that in our case these kinds of interactions are not the most important social factor in population self-regulation. We propose that other behavioural interactions and indirect communicative cues can be important in regulating the size of a population. Another explanation is that aggressive behaviour is directed at young individuals, the majority of which disappear (die or emigrate) from the enclosure population (Walkowa et al. 1989, Lukyanov et al. 1994). Also, relationships between residents in the enclosure may be established, with the result that their maintenance does not require a high level of aggression.

Our study was conducted on Mus musculus musculus, so differences from other data on the self-regulation hypothesis may be linked to the type of species studied. Most studies involving the self-regulation of house mice populations have concerned M.m.domesticus. Behaviour, including the level of aggression, can vary between different mouse populations and species (Sokolov et al. 1988, 1990).

There is a need for the roles of different types of behaviour (not only aggression) in the self-regulation of a population to be studied, with all the foregoing factors being taken into account. For this purpose experiments could be conducted with populations in different phases.

Acknowledgements: The authors' heartfelt thanks go to anonymous reviewers for their critical revision of the text and content of this manuscript. We are also grateful to K. Buczyńska for her help in the collection of material.

The research was in part made possible by Grants N NEX000 and N NEX300 from the International Science Foundation and the Russian Government and by Grant N 95-04-13113 from the Russian Foundation for Basic Research

\section{References}

Ambrose R. F. and Meehan T. E. 1977. Aggressive behavior of Perognatus parvus and Peromyscus maniculatus. Journal of Mammalogy 58: 665-668.

Andrzejewski R., Petrusewicz K. and Walkowa W. 1963. Absorption of newcomers by a population of white mice. Ekologia Polska, Seria A 11: 223-240.

Archer J. 1970. Effects of population density on behaviour in rodents. [In: Social behaviour in birds and mammals. J. H. Crook, ed]. London - New York: 169-210. 
Barnett S. A. and Evans C. S. 1965. Questions of the social dynamics of rodents. Symposia of the Zoological Society of London 14: 233-248.

Bronson F. H. 1979. The role of priming pheromones in mammalian reproductive strategies. [In: Chemical ecology: odour communication in animals. F. J. Ritter, ed]. North-Holland Biomedical Press, Amsterdam-Oxford: 97-104.

Chitty D. 1960. Population processes in the vole and their relevance to general theory. Canadian Journal of Zoology 38: 99-113.

Christian J. J. 1950. The adreno-pituitary system and population cycles in mammals. Journal of Mammalogy 31: 274-259.

Christian J. J. 1956. Adrenal and reproductive responses to population size in mice from freely growing populations. Ecology 37: 258-273.

Crowcroft P. 1954. Mouse research in Suffolk. Transactions of the Suffolk Natural Society 8: 185-187.

Crowcroft P. 1955. Territoriality in wild house mice, Mus musculus L. Journal of Mammalogy 36: 299-300.

Crowcroft P. and Rowe F. P. 1963. Social organization and territorial behaviour in the wild house mouse (Mus musculus L.). Proceedings of the Zoological Society of London 140: 517-531.

Drickamer L. C. 1986. Puberty-influencing chemosignals in house mice: Ecological and evolutionary aspects. [In: Chemical signals in vertebrates IV. D. Duvall, D. Muller-Schwarze and R. M. Silverstein, eds]. Plenum Press, New York: 441-455.

Ebert P. D. 1976. Agonistic behaviour in wild and inbred strains of Mus musculus. Behavioral Biology 18: 291-294.

Guralnik P. I., Kvashnin C. A. and Kniasev A. V. 1972. [The role of aggression in formation and maintenance of the group structure in house mice in experimental conditions]. [In: Ekologicheskie i evolucionnye aspekty povedenia zhivotnykh]. Nauka, Moscow: 232-234. [In Russian]

Hall E. R. 1927. An outbreak of house mice in Kern Country, California. University of California Publication in Zoology 30: 189-203.

Hurst J. L. and Berreen J. 1985. Observations on the trap-response of wild house mice Mus domesticus Rutty on poultry houses. Journal of Zoology 207: 619-622.

Kamenov D. A. 1973. [Ecological and physiological mechanisms of formation and maintenance of structure of house mice population]. Ph D thesis, University of Moscow, Moscow: 1-26. [In Russian]

Kotenkova E. V., Osipova O. V. and Lyalyukhina S. I. 1989. Repertory of postures and movements and seasonal changes in the social interactions in the mound-building mouse (Mus hortulanus Nord.). [In: Domovaja mysh. V. E. Sokolov, E.V. Kotenkova, B. R. Krasnov and N. N. Meshkova, eds]. Institute of Evolutionary Morphology and Ecology of Animals, UAS, Moscow: 256-272. [In Russian with English summary]

Krasnov B. R. 1988. Ecology of house mouse Mus musculus (Rodentia, Muridae) in conditions of north-east of the USSR. Zoologicheskyi Zhurnal 67: 102-110. [In Russian with English summary]

Krasnov B. R. and Khokhlova I. S. 1989. Lability of spatial-ethological structure of groups of house mouse as a strategy of adaptations to environmental conditions. [In: Domovaja mysh. V. E. Sokolov, E. V. Kotenkova B. R. Krasnov and N. N. Meshkova, eds]. Institute of Evolutionary Morphology and Ecology of Animals, UAS, Moscow: 223-235. [In Russian with English summary]

Krasnov B. R. and Khokhlova I. S. 1994. Spatial-ethological structure of groups. [In: The house mouse: origin, distribution, systematics, behavior. E. V. Kotenkova and N. Sh. Bulatova, eds]. Nauka, Moscow: 190-213. [In Russian with English summary]

Krebs C. J. 1970. Microtus population biology: behavioral changes associated with the population cycle in M. ochrogaster and M. pennsylvanicus. Ecology 51: 35-52.

Krebs Ch. J., Chitty D., Singleton G. and Boonstra R. 1995. Can changes in social behaviour help to explain house mouse plagues in Australia? Oikos 73: 429-434.

Lidicker W. Z. 1976. Social behaviour and density regulation in house mice living in large enclosures. Journal of Animal Ecology 45: 677-697. 
Llewellyn J. B. 1980. Seasonal change in the agrressive behaviour of Peromyscus maniculatus inhabiting a pinyon-juniper woodland in Western Nevada. Journal of Mammalogy 61: 341-345.

Lloyd I. A. and Christian J. J. 1967. Relationships of activity and aggression to density in two confined populations of house mouse (Mus musculus). Journal of Mammalogy 48: 262-269.

Lloyd I. A. 1975. Social structure and reproduction in two freely growing populations of house mice (Mus musculus L.). Animal Behavior 23: 413-424.

Lukyanov O., Walkowa W. and Adamczyk K. 1994. Analysis of mortality and emigration in a house mouse population. Polish Ecological Studies 20: 243-247.

Mackintosh J. H. 1973. Factors affecting the recognition of territory boundaries by mice (Mus musculus). Animal Behaviour 21: 464-470.

Mackintosh J. H. 1981. Behaviour of house mouse. Symposia of Zoological Society of London 47: 337-359.

McElman J. F. and Morris R. D. 1977. Patterns of behavior and outcomes of staged laboratory encounters between two voles species. Oikos 28: 276-284.

McShea W. J. 1990. Social tolerance and proximate mechanizms of dispersal among winter groups of meadow voles, Microtus pennsylvanicus. Animal Behaviour 39: 346-351.

Mihok S. 1976. Behaviour of subarctic red-backed voles (Clethrionomys gapperi athabascae). Canadian Journal of Zoology 54: 1932-1945.

Murie J. O. 1971. Behavioral relationships between two sympatric voles (Microtus): revelance to habitat segregation. Journal of Mammalogy 52: 181-186.

Petrusewicz K. and Andrzejewski R. 1962. Natural history of a free-living population of house mice (Mus musculus L.) with particular reference to groupings within the population. Ekologia Polska, Seria A, 10: 85-122.

Reimer J. D. and Petras M. L. 1967. Breeding structure of the house mouse (Mus musculus) in a population cage. Journal of Mammalogy 48: 88-99.

Rowe F. P. and Redfern R. 1969. Aggressive behaviour in related and unrelated wild house mice (Mus musculus L.). The Annales of Applied Biology 64: 425-431.

Singleton G. R. and Hay D. A. 1983. The effect of social organization on reproductive success and gene flow in colonies of wild house mice, Mus musculus. Behavioral Ecology and Sociobiology 12: 49-56.

Sokolov V. E., Zagoruiko N. V., Kotenkova E. V. and Lyalyukhina S. I. 1988. Comparative analysis of behavior in house (Mus musculus musculus) and mound-building ( $M$. hortulanus) mice in groups. Zoologicheskyi Zhurnal 67: 1214-1224. [In Russian with English summary]

Sokolov V. E., Kotenkova E. V. and Lyalyukhina S. I. 1990. Biology of House and Mound-bilding mice. Nauka, Moscow: 1-208. [In Russian with English summary]

Southwick C. H. 1958. Population characteristics of house mice living in English corn-ricks: density relationships. Proceedings of the Zoological Society of London 131: 163-175.

Turner B. N. and Iverson S. L. 1973. The annual cycle of aggression in male Microtus pennsylvanicus, and its relation to population parameters. Ecology 54: 967-980.

Viitala J. 1981. On the role of aggression population regulation of small mammals rodents. Memoranda Societatis pro Fauna et Flora Fennica 57: 20.

Walkowa W., Adamczyk K. and Chełkowska H. 1989. Characteristics of migrants in a free-living population of the house mouse. Acta Theriologica 34: 305-313.

Young H., Strecker R. L. and Emlen J. T. 1950. Localization of activity of two indoor populations of house mice. Journal of Mammalogy 31: 403-410.

Zegeren K., van. 1980. Variations in aggressiveness and the regulation of numbers in house mouse population. Netherlands Journal of Zoology 30, 4: 635-770.

Zolotarev S. V. 1980. [Rank order estimating factors in males in groups of feral house mouse]. $\mathrm{Ph} \mathrm{D}$ thesis, University of Moscow, Moscow: 1-24. [In Russian]

Received 12 December 1996, revised 7 February 1998, accepted 17 July 1998. 